\title{
REDUKSI MISKONSEPSI KINEMATIKA SISWA MELALUI MODEL KOOPERATIF STRATEGI KONFLIK KOGNITIF BERBANTUAN KIT DAN PhET
}

\author{
Dian Mufarridah \\ SMA Negeri 2 Bontang \\ Jl. H. M. Ardans Bontang Selatan-Bontang-Kalimantan Timur \\ e-mail: dian.mufarridah@yahoo.com
}

\begin{abstract}
Misconceptions on kinematics experienced by $20 \%$ of students of X IPA 2 SMAN 2 Bontang. This problem is as a great reason for solving the barriers, as a way to improve the students'achievement. This study aimed to describe the learning process and reduction of students' misconceptions. This study is a classroom action research. This study was carred out two cycles, namely cycle I and continued in process cycle II. Each cycles consist of four components, namely planning, action, observation, and reflection. This study was in SMAN 2 Bontang, the total subject of this study is 34 students of X IPA 2 . The data is collected through observation, interviews, questionnaires, and test conception. The conception test is multiple choice test. The number of test item are ten items followed by Certainty of Response Index (CRI) and argument-respons. The test is used to know the concept knowledge students, and the arguments is used to make sure the student'knowledge about conception. The analysis method used is descriptive qualitative. The results of the study showed that average students in mastering concept improve and students achievement improve from 41,93 and $0 \%$ (preaction) to 63,12 and $44,1 \%$ ( cycle I ) to 80,78 and $91,2 \%$ ( cycle II ). CRI analysis result and coding argument show that student's misconception of eight concepts tested is reduced. It can be conclude that the use of cooperative learning model based KIT and PhET can improve the learning process and reduce misconception students.
\end{abstract}

Keywords: Misconceptions, Cognitive Conflict Strategy

Abstrak : Miskonsepsi pada materi kinematika gerak lurus dialami oleh 20\% siswa kelas X IPA 2 SMAN 2 Bontang. Hal ini menjadi landasan kuat bahwa tindakan untuk mengatasi hambatan-hambatan dalam pembelajaran diperlukan sebagai langkah perbaikan. Penelitian ini bertujuan mendeskripsikan pelaksanaan pembelajaran dan reduksi miskonsepsi siswa. Penelitian ini merupakan Penelitian Tindakan Kelas (PTK). PTK direncanakan dua siklus, yaitu siklus I dan dilanjutkan pada proses siklus II. Setiap siklus terdiri atas empat komponen, yaitu perencanaan, tindakan, pengamatan, dan refleksi. Penelitian dilaksanakan di SMAN 2 Bontang dengan subyek penelitian siswa kelas X IPA 2 berjumlah 34 orang. Data dikumpulkan melalui observasi, wawancara, angket, dan tes konsepsi. Tes konsepsi berbentuk pilihan ganda sebanyak sepuluh nomor disertai Certainty of Response Index (CRI) dan argumentasi jawaban. Tes digunakan untuk mengungkap konsepsi siswa, argumentasi digunakan untuk menegaskan konsep siswa secara lebih dalam. Metode analisis yang digunakan adalah analisis deskriptif kualitatif. Hasil penelitian menunjukkan bahwa rata-rata penguasaan konsep siswa dan ketuntasan meningkat dari 41,93 dan $0 \%$ (prapenelitian) menjadi 63,12 dan 44,1\% (siklus I) kemudian menjadi 80,78 dan 91,2\% (siklus II). Hasil analisis CRI dan pengkodean argumentasi menunjukkan bahwa miskonsepsi siswa terhadap delapan konsep yang diujikan mengalami reduksi. Dapat disimpulkan bahwa penggunaan model pembelajaran kooperatif strategi konflik kognitif berbantuan KIT dan PhET dapat meningkatkan proses dan mereduksi miskonsepsi siswa.

Kata kunci: Miskonsepsi, Strategi Konflik Kognitif

\section{PENDAHULUAN}

Dua faktor yang ikut berperan dalam masalah belajar siswa adalah prakonsepsi dan miskonsepsi. Dilber et al. (2007) menyatakan bahwa guru harus peduli terhadap prakonsepsi dan miskonsepsi siswa, karena kedua faktor tersebut merupakan faktor penting untuk meningkatkan hasil belajar siswa.

Miskonsepsi siswa yang muncul terus menerus akan mengganggu pembentukan konsepsi ilmiah dan mengakibatkan masalah belajar yang dapat mempengaruhi hasil belajar siswa. Trumper (1990) mengungkapkan bahwa kesulitan belajar fisika siswa menyebabkan penguasaan konsep siswa rendah. Penguasaan konsep fisika yang rendah menyebabkan rendahnya mutu pendidikan fisika.

PBM yang cenderung bersifat teacher-centered menimbulkan masalah bagi siswa, yaitu siswa menjadi kurang: termotivasi, aktif, terampil, dan kritis dalam menganalisis kasus fisika. Miskonsepsi terhadap berbagai topik diduga menjadi penyebab rendahnya 
pencapaian persentase penguasaan siswa SMAN 2 Bontang pada Ujian Nasional (UN) tiga tahun terakhir. Salah satu indikator, terdapat rentang nilai mata pelajaran fisika yang cukup besar antara nilai tertinggi dan terendah yang dapat dicapai siswa. Tahun Pelajaran (TP) 2010/2011 nilai terendah 3,50 dan nilai tertinggi 9,50. TP 2011/2012 nilai terendah 2,75 dan nilai tertinggi 9,25. Sedangkan TP 2012/2013 nilai terendah 3,25 dan nilai tertinggi 8,00. (Sumber: Data Dinas Provinsi Kalimantan Timur).

Miskonsepsi siswa banyak ditemui dalam pembelajaran fisika di sekolah, antara lain pada pokok bahasan gerak (Sadia, 2004; Saehana dkk, 2009; Mukti, 2010; dan Pujianto, 2013), suhu dan kalor (Baser, 2006; Sirait, 2009; dan Mosik, 2010), fluida (Said, 2012), cahaya (Indrawati, 2009), listrik dinamis (Dilber et al., 2007; Tsai, C-H. et al., 2007; Kucukozer et al., 2007; Simarmata, 2008; Dilber et al., 2008; Faizin, 2009; dan Smith et al., 2011), listrik magnet (Raduta, 2005; Triyana, 2009).

Berdasarkan hasil temuan beberapa penelitian di atas, dapat disimpulkan bahwa miskonsepsi dalam pembelajaran fisika terjadi pada hampir semua topik fisika. Pokok bahasan kinematika gerak lurus termasuk salah satu topik di mana miskonsepsi banyak terjadi.

Miskonsepsi dapat dialami oleh berbagai komponen yang terlibat dalam pembelajaran. Miskonsepsi timbul karena kesalahan pemahaman terhadap suatu konsep. Hasil penelitian menunjukkan bahwa ada banyak kesalahan dalam konsep kinematika gerak lurus yang dimiliki siswa, guru, maupun yang tertulis di dalam buku pegangan. Hal ini sesuai dengan temuan Mukti dkk. (2010) yang menyatakan bahwa $7,2 \%$ atau sembilan dari tiga puluh konsep materi kinematika gerak lurus yang tertulis di dalam buku pegangan berpotensi miskonsepsi. Mudjiarto (2005) menyatakan bahwa siswa kelas 1 pada salah satu SMU Negeri di Bandung mengalami miskonsepsi kinematika gerak lurus di atas 10\%. Sedangkan, Pujianto dkk. (2013) menemukan bahwa 50\% konsepsi kinematika gerak lurus siswa pada salah satu SMA di kota Palu mengarah pada miskonsepsi.

Miskonsepsi pada pokok bahasan kinematika gerak lurus juga dialami oleh siswa SMAN 2 Bontang. Berdasarkan hasil prapenelitian oleh penulis yang dilaksanakan pada 34 siswa kelas X IPA 2 Tahun Pelajaran 2013/2014, ditemukan bahwa siswa mengalami miskonsepsi pada pokok bahasan tersebut lebih besar dari 20\%. (Sumber: Data prapenelitian).

Sehubungan dengan temuan hasil belajar siswa SMAN 2 Bontang dan hasil penelitian tersebut di atas, perlu dilakukan reorientasi dalam pembelajaran fisika khususnya pada pokok bahasan kinematika gerak lurus.
Salah satu strategi belajar yang telah terbukti efektif untuk mereduksi miskonsepsi siswa adalah strategi konflik kognitif. Hal ini sesuai dengan temuan Baser (2006), Sirait (2009), dan Mosik (2010) yang menyatakan bahwa penggunaan strategi konflik kognitif secara signifikan dapat meningkatkan pemahaman konsep fisika, kemampuan berpikir kritis, dan menurunkan miskonsepsi. Selain itu, Simarmata (2008) menemukan bahwa pendekatan konflik kognitif dalam pembelajaran konstruktivis dapat meningkatkan belajar mandiri siswa dan lebih efektif meluruskan kesalahan konsep siswa.

Pembelajaran fisika yang efektif dapat dilakukan dengan memperkenalkan multimedia sebagai salah satu sarana alternatif pendukung PBM, antara lain penggunaan media komputer dan KIT. Kebermanfaatan pembelajaran berbasis komputer dapat dilihat dari hasil temuan Mardana (2004), Saehana, dkk (2006), dan Faizin (2009) yang menyatakan bahwa model pembelajaran berbantuan simulasi komputer secara signifikan dapat menurunkan miskonsepsi, meningkatkan hasil belajar fisika, meningkatkan penguasaan konsep, dan juga dapat memperbaiki sikap belajar.

Berdasarkan hal-hal yang telah dikemukakan pada bagian sebelumnya, penelitian tindakan kelas ini mendasarkan pada upaya mengatasi miskonsepsi siswa dengan mendesain pembelajaran yang menarik, yaitu dengan menerapkan model pembelajaran kooperatif strategi konflik kognitif berbantuan KIT dan PhET. Diharapkan dengan model pembelajaran tersebut, motivasi, keberanian mengkritisi fenomena, dan keterampilan siswa dalam berargumentasi semakin meningkat.

Studi ini memberikan gambaran implementasi pembelajaran kooperatif dengan strategi konflik kognitif berbantuan KIT dan PhET dalam mereduksi miskonsepsi siswa terhadap materi kinematika gerak lurus. Secara spesifik penelitian ini menjawab pertanyaan-pertanyaan penelitian sebagai berikut: (1) Bagaimanakah pelaksanaan pembelajaran kooperatif berbantuan KIT dan PhET dalam mereduksi miskonsepsi siswa kelas X IPA 2 SMAN 2 Bontang?; (2) Bagaimanakah reduksi miskonsepsi siswa kelas $X$ IPA 2 SMAN 2 Bontang dengan model pembelajaran kooperatif strategi konflik kognitif berbantuan KIT dan PhET?

\section{METODE PENELITIAN}

Penelitian ini merupakan Penelitian Tindakan Kelas (PTK) dengan desain penelitian model Kurt Lewin. Penelitian ini dilaksanakan di SMAN 2 Bontang tahun pelajaran 2013/2014 dengan subyek penelitian siswa kelas X IPA 2 berjumlah 34 orang. PTK ini 
direncanakan dua siklus, yaitu siklus I dan dilanjutkan pada proses siklus II. Tiap-tiap proses siklus terdiri atas empat tindakan, yaitu perencanaan (planning), tindakan (acting), pengamatan (observing), dan refleksi (reflecting). Bagan siklus penelitian disajikan pada Gambar 1 berikut.

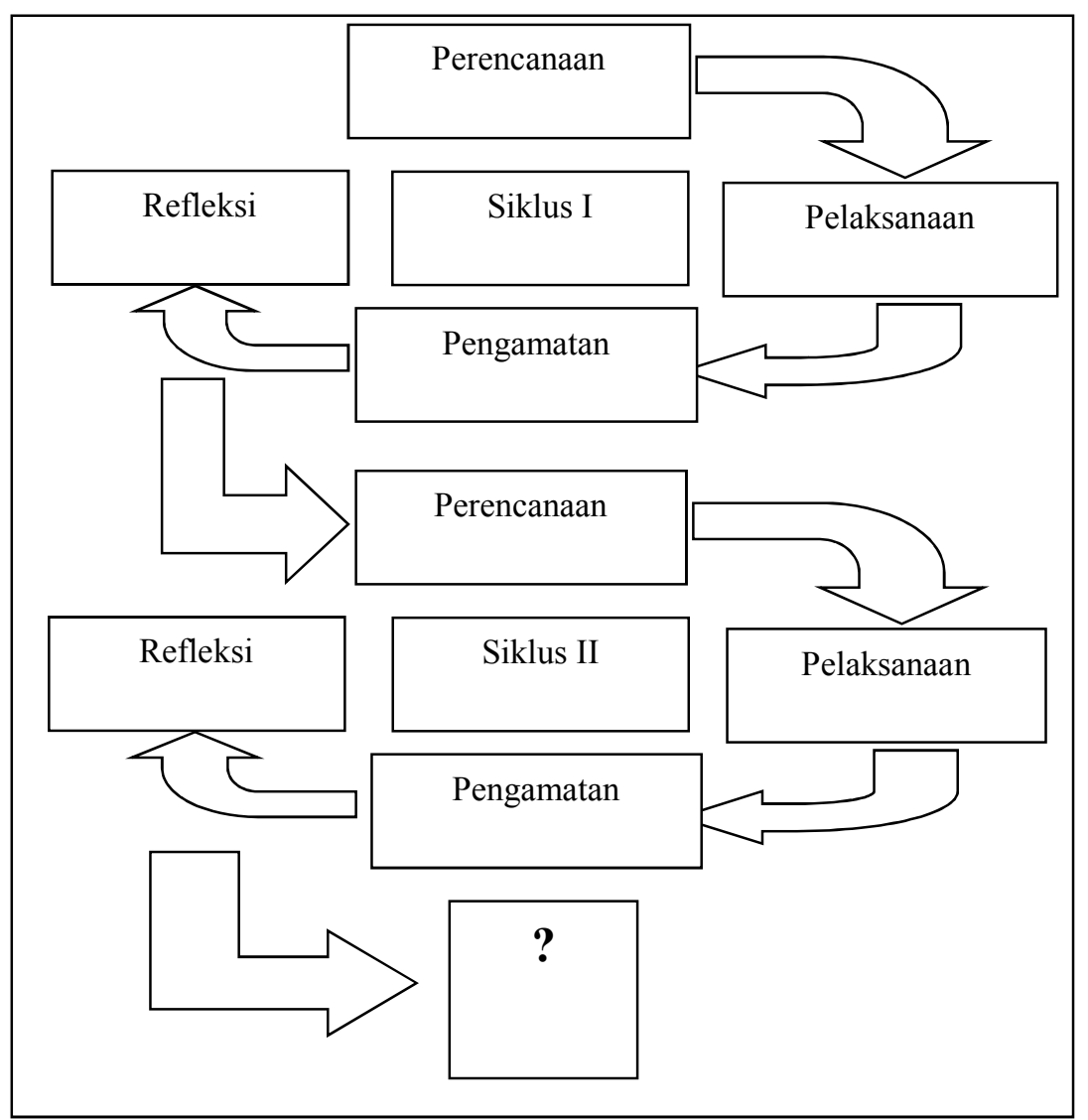

Gambar 1. Bagan Siklus Penelitian

Instrumen penelitian yang digunakan untuk mengumpulkan data adalah: lembar observasi, pedoman wawancara, angket, dan tes konsepsi.

Tes konsepsi terdiri dari delapan konsep yang tersebar dalam sepuluh butir soal pilihan ganda dengan argumentasi jawaban dan disertai CRI. Delapan konsep tersebut adalah: gerak lurus dalam kehidupan seharihari (butir 1), jarak dan perpindahan (butir 2 dan 3), kelajuan dan kecepatan (butir 4 dan 5), percepatan (butir 6), gerak lurus beraturan (butir 7), gerak lurus berubah beraturan (butir soal 8), gerak lurus diperlambat (butir 9), dan gerak jatuh bebas (butir 10).

Data yang dianalisis dalam penelitian ini adalah catatan lapangan yang diperoleh dari peneliti, hasil observasi dari observer, dan balikan dari siswa. Teknik analisis data menggunakan teknik deskriptif kualitatif.

Validasi data yang telah terkumpul dilakukan dengan beberapa cara, yaitu: member check, triangulasi, dan saturasi. Identifikasi miskonsepsi dilakukan dengan menggunakan dua teknik, yaitu: CRI (Certainty of Response Index) digunakan untuk mendeteksi miskonsepsi pada soal pilihan ganda, dan pengkodean argumentasi digunakan untuk mendeteksi miskonsepsi pada argumentasi siswa.
Identifikasi miskonsepsi menggunakan CRI dilakukan secara individu dan kelompok. Pengidentifikasian secara individu dimaksudkan untuk mengetahui persentase siswa yang mengalami miskonsepsi pada sejumlah konsep yang diberikan.

Pada setiap item soal, siswa diminta untuk mengisi skala CRI di tempat yang telah disediakan dengan enam skala yaitu seperti ditunjukkan pada Tabel 1 .

Tabel 1. Kategori Keyakinan Menjawab (CRI)

\begin{tabular}{|c|l|c|}
\hline Skala & \multicolumn{1}{|c|}{ Kategori } & $\begin{array}{c}\text { Persentase } \\
\text { Tebakan }\end{array}$ \\
\hline 0 & $\begin{array}{l}\text { Benar-benar menerka } \\
\text { jawaban (totally guessed } \\
\text { answer) }\end{array}$ & $100 \%$ \\
\hline 1 & $\begin{array}{l}\text { Hampir menduga (almost } a \\
\text { guess) }\end{array}$ & $75 \%-99 \%$ \\
\hline 2 & Tidak yakin (not sure) & $50 \%-74 \%$ \\
\hline 3 & Yakin (sure) & $25 \%-49 \%$ \\
\hline 4 & $\begin{array}{l}\text { Hampir pasti (almost } \\
\text { certain) }\end{array}$ & $1 \%-24 \%$ \\
\hline 5 & Pasti (certain) & $0 \%$ \\
\hline
\end{tabular}


Dari data yang terkumpul dibuat matriks untuk setiap pertanyaan. Bentuk matriks jawaban siswa secara individu dapat dilihat pada Tabel 2.

Tabel 2. Penentuan Tingkat Pemahaman Konsep

\begin{tabular}{|c|l|l|}
\hline $\begin{array}{c}\text { Tipe } \\
\text { Jawaban }\end{array}$ & $\begin{array}{c}\text { CRI Rendah } \\
(<\mathbf{2 , 5})\end{array}$ & $\begin{array}{c}\text { CRI Tinggi } \\
(>\mathbf{2 , 5})\end{array}$ \\
\hline $\begin{array}{c}\text { Jawaban } \\
\text { benar }\end{array}$ & $\begin{array}{l}\text { Siswa menjawab } \\
\text { benar karena } \\
\text { keberuntungan } \\
\text { (lucky guess) }\end{array}$ & $\begin{array}{l}\text { Siswa menguasai } \\
\text { konsep dengan } \\
\text { baik }\end{array}$ \\
\hline $\begin{array}{c}\text { Jawaban } \\
\text { salah }\end{array}$ & $\begin{array}{l}\text { Siswa tidak tahu } \\
\text { konsep (lack of } \\
\text { knowledge) }\end{array}$ & $\begin{array}{l}\text { Siswa } \\
\text { mengalami } \\
\text { miskonsepsi }\end{array}$ \\
\hline \multicolumn{2}{|r}{ (Hasan et al., 1999) } \\
\hline
\end{tabular}

Pengidentifikasian miskonsepsi menggunakan CRI secara kelompok dimaksudkan untuk mengetahui konsep apa yang memiliki level miskonsepsi paling tinggi di antara konsep lainnya. Identifikasi secara kelompok ditentukan dari nilai CRIB (rata-rata CRI siswa yang menjawab benar), CRIS (rata-rata CRI siswa yang menjawab salah), dan $\mathrm{Fb}$ (fraksi siswa yang menjawab benar).

Miskonsepsi terjadi jika nilai CRIS $(2,5<$ CRIS $\leq$ 5). Jika CRIS mendekati 2,5, maka untuk menentukan siswa mengalami miskonsepsi atau tidak dilihat dari nilai $\mathrm{Fb}$. Jika $\mathrm{Fb}>0,5$ berarti CRIS tergolong rendah, sehingga siswa dianggap tidak tahu konsep. Jika $\mathrm{Fb}<$ 0,5 berarti CRIS tergolong tinggi, sehingga siswa dianggap miskonsepsi. Semakin tinggi nilai CRIS, maka tingkat miskonsepsi juga semakin tinggi karena keyakinan yang ditunjukkan siswa juga tinggi meskipun memilih jawaban yang salah.

Panduan untuk menganalisis argumentasi yang diberikan siswa pada tes pemahaman konsep sebagai panduan mengidentifikasi adanya miskonsepsi disajikan sebagai berikut:

a. Secara ilmiah benar (A) : penjelasan benar secara ilmiah.

b. Mendekati benar (B) : penjelasan yang diberikan benar tetapi dalam penjelasanlengkap dianggap berada di tingkat ini.

c. Tidak benar $1(\mathrm{C})$ : secara ide benar namun kalimat yang dipergunakan untuk menjelaskan salah.

d. Tidak benar 2 (D) : penjelasan terfokus pada bagian kecil dan bagian besar dari suatu konsep, namun cara menghubungkannya sesuai dengan level ini.

e. Tidak benar 3 (E) : ide mengenai konsep dan penjelasan yang diberikan tidak dapat dibenarkan secara ilmiah.

f. Tidak terkodekan (F) : penjelasan yang diberikan tidak berhubungan dengan soal yang diajukan.

g. Tidak ada penjelasan $(\mathrm{G})$ : siswa tidak memberikan argumentasi (Kucukozer et al., 2007).

Indikator keberhasilan dalam penelitian ini adalah 85\% siswa kelas X IPA 2 SMAN 2 Bontang mencapai Kriteria Ketuntasan Minimal yang ditetapkan, yaitu 70.

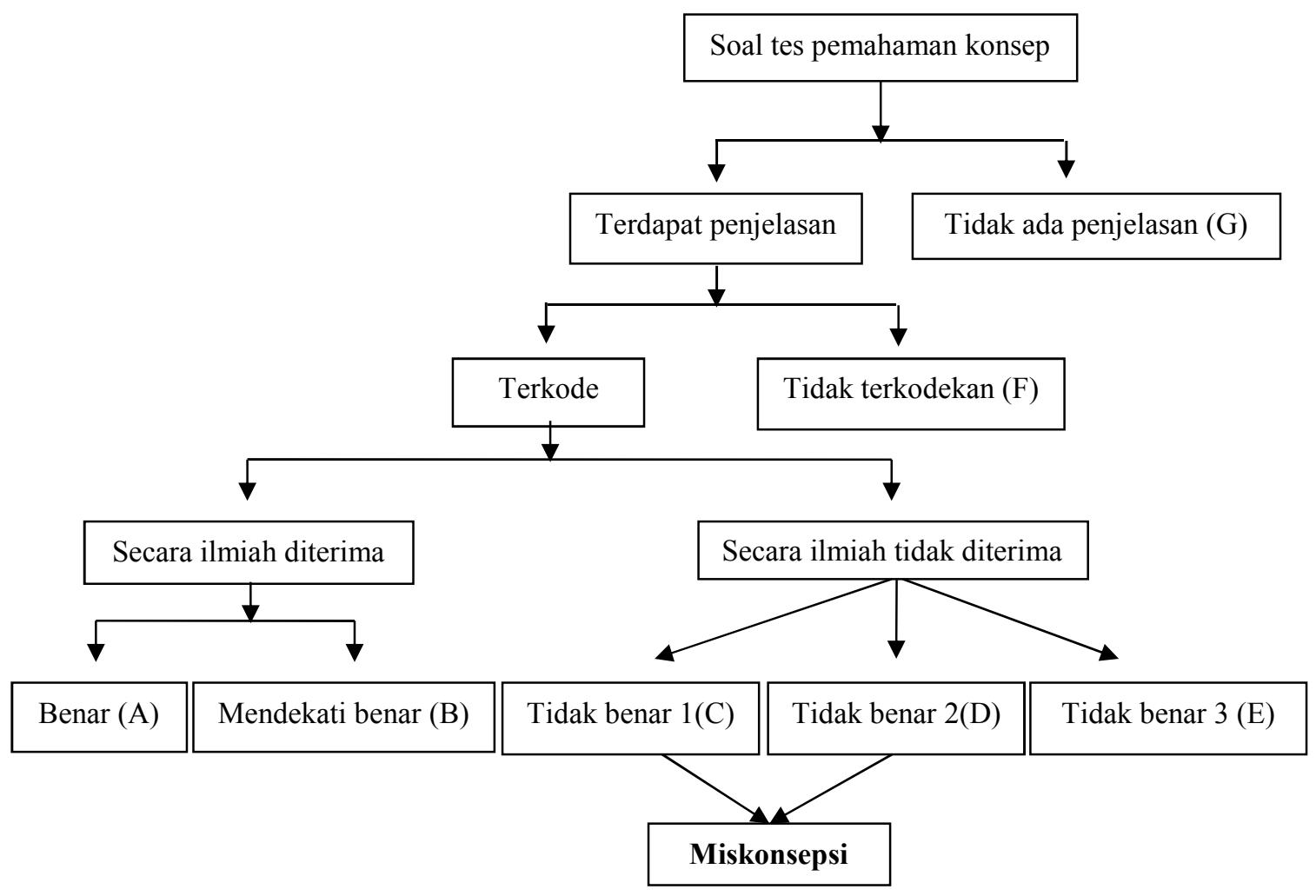

Gambar 2. Analisis Terhadap Tes Pemahaman Konsep (Kucukozer et al., 2007) 


\section{HASIL PENELITIAN DAN DISKUSI}

\section{A. Deskripsi Hasil Prapenelitian}

Pada tahap prapenelitian, siswa sebelumnya diberikan pretest untuk mengidentifikasi miskonsepsi siswa, baik pada jawaban pilihan ganda maupun argumentasi. Hasil identifikasi CRI disajikan pada Gambar 3, sedangkan pengkodean argumentasi pada Gambar 4.

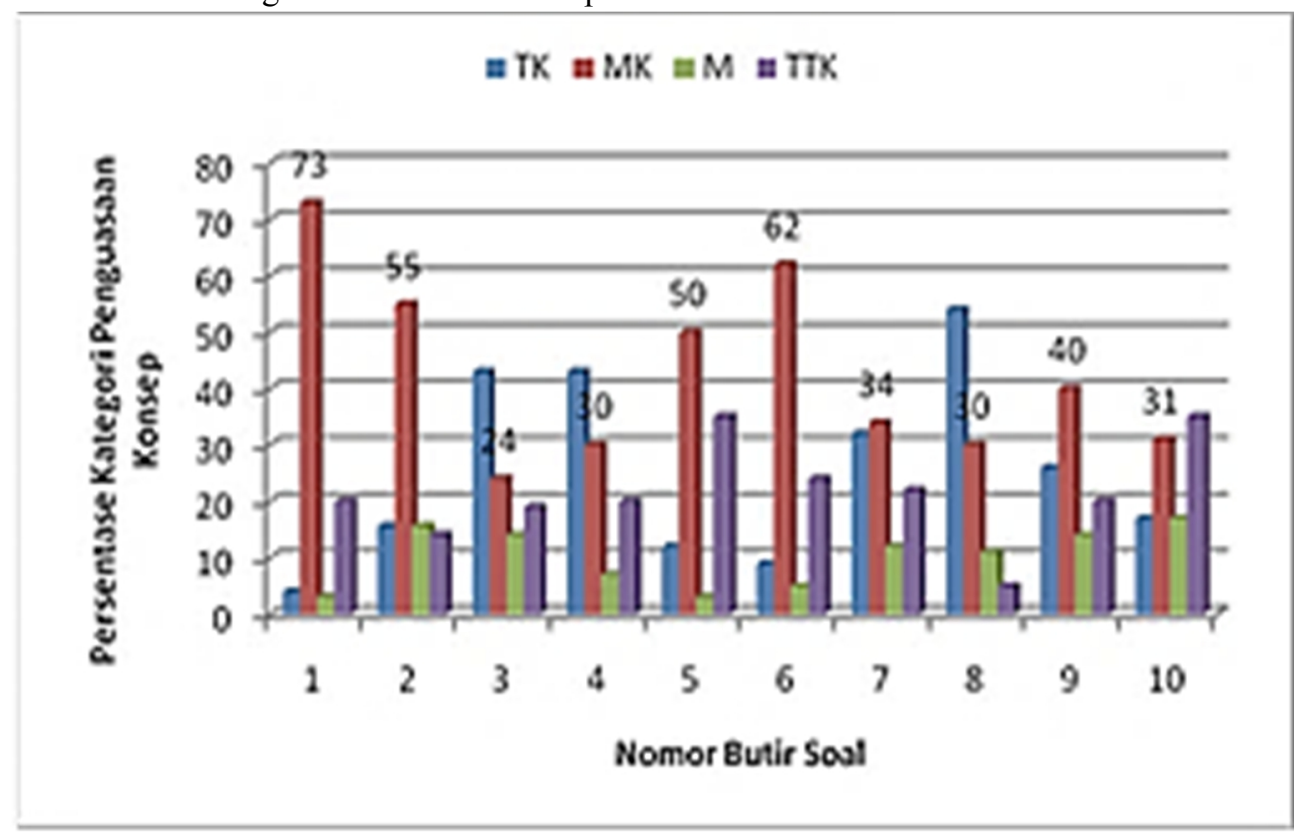

Gambar 3. Profil Tingkat Penguasaan Konsep Siswa

Berdasarkan hasil identifikasi profil miskonsepsi pada Gambar 3, secara individu ditemukan adanya miskonsepsi terhadap delapan konsep yang tersebar dalam sepuluh butir soal yang diujikan pada pretest dengan persentase lebih besar dari $20 \%$.

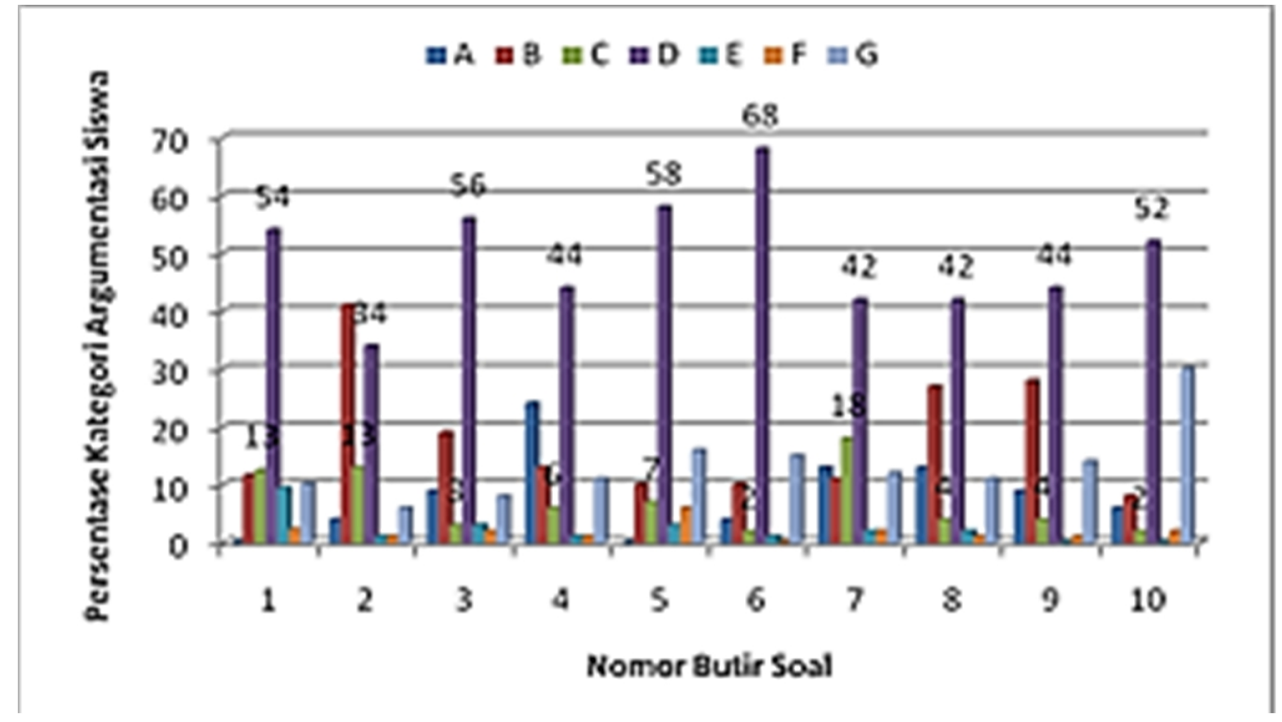

Gambar 4. Profil Miskonsepsi Argumentasi Siswa

Berdasarkan hasil identifikasi profil miskonsepsi argumentasi pada Gambar 4, ditemukan adanya miskonsepsi argumentasi terhadap delapan konsep yang tersebar dalam sepuluh butir soal yang diujikan pada pretest dengan persentase lebih besar dari $45 \%$.

Pemahaman siswa yang berada pada kategori miskonsepsi pada konsep gerak lurus dalam kehidupan sehari-hari adalah sebesar $73 \%$. Sedangkan, persentase argumentasi siswa berkategori miskonsepsi (kode $\mathrm{C}$ dan D) adalah 67\%. Argumentasi siswa berlabel miskonsepsi antara lain: (a) gerak kelereng yang disentil dari ujung meja merupakan gerak lurus, (b) bola sepak yang ditendang melambung bukan merupakan gerak lurus, dan (c) buah kelapa yang jatuh dari pohonnya bukan merupakan gerak lurus. Argumentasiargumentasi tersebut mungkin disebabkan oleh pengalaman siswa yang kurang.

Senada dengan miskonsepsi argumentasi (b) yang dialami oleh siswa SMAN 2 Bontang, Pujianto dkk. 
(2013) menuliskan bahwa siswa kelas X SMA Negeri 6 Palu mengalami miskonsepsi sebesar 33,33\%.

Berdasarkan hasil wawancara terhadap perwakilan siswa dari masing-masing kelompok, didapatkan bahwa faktor yang diduga sebagai sumber miskonsepsi yang dialami siswa pada konsep ini adalah guru, buku, teman, dan lingkungan. Dengan demikian dapat dikatakan bahwa siswa masih membawa pengalaman dari pengalaman belajar di tingkat sebelumnya.

Mukti dkk. (2010) menyatakan bahwa 7,2\% atau sembilan dari tiga puluh konsep materi kinematika gerak lurus yang tertulis di dalam buku pegangan berpotensi miskonsepsi. Sumber belajar yang memberikan pengalaman belajar yang tidak sesuai dengan konsepsi ilmiah, dapat memicu terjadinya miskonsepsi pada siswa (Ibrahim, 2012: 16).

Siswa mengalami miskonsepsi terhadap konsep jarak dan perpindahan sebesar $40 \%$. Sedangkan, persentase argumentasi siswa berkategori miskonsepsi adalah 53\%. Mudjiarto (2005) menemukan bahwa siswa kelas 1 pada salah satu SMA Negeri di Kota Bandung mengalami miskonsepsi konsep jarak dan perpindahan diatas $10 \%$.

Argumentasi siswa yang berlabel miskonsepsi terhadap konsep tersebut antara lain: (a) jarak sama dengan perpindahan, (b) benda yang kembali ke posisi awal mengalami perpindahan, (c) jarak tempuh benda bergerak dan kembali ke posisi awal adalah nol, dan (d) jarak ditentukan oleh kedudukan awal dan akhir, sedangkan perpindahan tidak.

Pujianto dkk. (2013) menuliskan bahwa 50\% siswa kelas X SMA Negeri 6 Palu mengalami miskonsepsi argumentasi yang senada dengan argumentasi (d) yaitu jarak ditentukan oleh arah, sedangkan perpindahan tidak.

Miskonsepsi argumentasi dikarenakan siswa tidak memahami karakteristik jarak dan perpindahan secara utuh. Dengan kata lain siswa tidak mampu membedakan karakteristik penentu yaitu posisi dari sejumlah karakteristik umum yang dimiliki oleh konsep pada jarak dan perpindahan. Reasioning yang tidak lengkap merupakan salah satu penyebab terjadinya miskonsepsi pada siswa (Ibrahim, 2012: 14).

Persentase pemahaman siswa terhadap konsep kelajuan dan kecepatan yang berkategori miskonsepsi adalah sebesar $40 \%$. Argumentasi siswa yang berlabel miskonsepsi terhadap konsep tersebut sebesar $58 \%$. Miskonsepsi argumentasi yang dikemukakan siswa antara lain: (a) kelajuan sama dengan kecepatan, (b) spidometer digunakan untuk mengukur kecepatan, dan (c) mobil yang dapat menyalip mobil yang lain pasti kecepatannya sama.

Pujianto dkk. (2013) dalam penelitiannya mendapatkan bahwa $37,50 \%$ siswa kelas X SMA Negeri 6 Palu mengalami miskonsepsi terhadap konsep kelajuan dan kecepatan. Ketidakmampuan siswa dalam menguasai konsep jarak dan perpindahan sebagai konsep prasyarat dari konsep kelajuan dan kecepatan mengantarkan siswa pada miskonsepsi (Ibrahim, 2012: 14).

Siswa mengalami miskonsepsi terhadap konsep percepatan sebesar $62 \%$. Sedangkan, persentase argumentasi siswa berkategori miskonsepsi adalah $70 \%$. Miskonsepsi argumentasi antara lain: (a) jika perubahan kecepatan mobil ke dua bernilai tetap walaupun lebih besar daripada perubahan kecepatan mobil pertama, maka mobil ke dua tidak akan pernah menyusul mobil pertama, dan (b) mobil mengalami perubahan kecepatan ketika melaju dengan kecepatan tinggi.

Jika argumentasi di atas dianalisis, maka tampak bahwa siswa fokus pada bagian kecil tertentu yaitu kecepatan. Terlihat bahwa logika atau penalaran yang digunakan siswa dalam menarik kesimpulan atau menggeneralisasi salah. Dengan pemikiran yang tidak lengkap seperti ini dapat mengakibatkan terjadinya miskonsepsi (Ibrahim, 2012: 14).

Miskonsepsi terhadap konsep percepatan juga dialami $62,50 \%$ siswa kelas X SMA Negeri 6 Palu sebagaimana yang dilaporkan Pujianto dkk. (2013). Senada dengan itu, Mudjianto (2005) menemukan bahwa lebih dari $30 \%$ siswa kelas 1 pada salah satu SMA Negeri di Kota Bandung mengalami miskonsepsi pada konsep kecepatan dan percepatan.

Miskonsepsi terhadap konsep gerak lurus beraturan dialami oleh $34 \%$ siswa. Argumentasi siswa berkategori miskonsepsi adalah sebesar 60\%. Argumentasi berlabel miskonsepsi antara lain: (a) balok tidak akan bergerak jika gaya dorong dihilangkan, dan (b) benda yang bergerak di atas lantai licin tetap mengalami percepatan walaupun gaya dorong dihilangkan. Argumentasi ini dikarenakan penguasaan konsep siswa yang tidak lengkap dan salah dalam menggeneralisasi sehingga memicu terjadinya miskonsepsi (Ibrahim, 2012: 14).

Pujianto dkk. (2013) dalam penelitiannya menemukan bahwa $45,83 \%$ siswa kelas X SMA Negeri 6 Palu mengalami miskonsepsi terhadap konsep gerak lurys beraturan. Sedangkan, Mudjianto (2005) menemukan bahwa lebih dari $10 \%$ siswa kelas 1 pada salah satu SMA Negeri di Kota Bandung mengalami miskonsepsi terhadap konsep yang sama.

Siswa mengalami miskonsepsi terhadap konsep gerak lurus berubah beraturan sebesar $30 \%$. Sedangkan, persentase argumentasi siswa berkategori miskonsepsi adalah 46\%. Miskonsepsi argumentasi tersebut antara lain: (a) benda yang kecepatannya menurun tidak mengalami percepatan, (b) benda yang kecepatannya berubah termasuk gerak lurus beraturan, dan (c) jarak yang terjadi pada mobil tidak terlalu berjauhan sehingga bisa dikatakan percepatannya tetap. 
Mudjianto (2005) menemukan bahwa lebih dari $10 \%$ siswa kelas 1 pada salah satu SMA Negeri di Kota Bandung mengalami miskonsepsi terhadap konsep tersebut. Sedangkan, Pujianto dkk. (2013) menuliskan bahwa $62,50 \%$ siswa kelas X SMA Negeri 6 Palu mengalami miskonsepsi terhadap konsep yang sama dengan argumentasi mobil yang sedang melaju dengan kecepatan tetap merupakan gerak lurus berubah beraturan dipercepat. Ketidakmampuan siswa dalam menguasai konsep percepatan sebagai konsep prasyarat dari konsep gerak lurus berubah beraturan mengantarkan siswa pada miskonsepsi (Ibrahim, 2012: 14).

Miskonsepsi terhadap konsep gerak lurus diperlambat dialami $40 \%$ siswa. Persentase argumentasi siswa berkategori miskonsepsi adalah $48 \%$. Argumentasi tersebut antara lain: (a) apabila mobil diperlambat, maka percepatan mobil tersebut konstan, dan (b) mobil mengalami perubahan percepatan ketika mobil di rem.

Pujianto dkk. (2013) menuliskan bahwa 33,33\% siswa kelas X SMA Negeri 6 Palu mengalami miskonsepsi terhadap konsep ini, dengan argumentasi belum pernah mendengar tentang gerak lurus diperlambat. Menurut Ibrahim (2012: 16) bahwa "anggapan pribadi" atau intuisi yang salah sering membuat siswa tidak kritis dan mengakibatkan miskonsepsi dikalangan siswa.

Siswa mengalami miskonsepsi terhadap konsep gerak jatuh bebas sebesar 31\%. Sedangkan, persentase argumentasi siswa berkategori miskonsepsi adalah $54 \%$. Argumentasi berlabel miskonsepsi tersebut antara lain: (a) benda-benda akan memiliki massa yang sama jika berada di dalam tabung hampa udara, sehingga akan sampai ke tanah bersamaan, (b) benda yang massanya lebih besar akan sampai ke tanah lebih dahulu dalam ruang hampa, dan (c) benda kehilangan massa ketika berada di dalam tabung hampa udara.

Siswa memberikan argumentasi-argumentasi di atas berdasarkan pengalaman yang diperoleh dari lingkungan, salah satunya karena pengaruh bahasa keseharian, misalkan menyebut istilah massa dengan berat. Informasi yang salah atau penjelasan yang berbeda dari latar belakang lingkungan siswa dapat menyebabkan terjadi miskonsepsi pada siswa (Ibrahim, 2012: 16).

Rerata penguasaan konsep siswa hasil pretest adalah 41,93 dengan ketuntasan $0 \%$. Hal ini menunjukkan bahwa rerata dan ketuntasan siswa berada di bawah KKM KD dan KKM klasikal. Baik hasil pretest yang tampak pada tabel dan deskripsi di atas menjadi landasan kuat bahwa tindakan untuk mengatasi hambatan-hambatan atau kekurangan dalam pembelajaran diperlukan sebagai langkah perbaikan.

\section{B. Deskripsi Hasil Siklus I}

Model yang digunakan dalam siklus I adalah model kooperatif strategi konflik kognitif berbantuan KIT dan PhET. Konflik kognitif dimunculkan melalui kegiatan eksperimen menggunakan KIT dan PhET.

Tahap perencanaan dilakukan setelah peneliti dengan kolaborator berdiskusi tentang data yang telah dihasilkan dari prapenelitian yaitu penguasaan konsep siswa yang berlabel miskonsepsi.

Berdasarkan masalah yang ditentukan, peneliti dan kolaborator menentukan alternatif pemecahan masalah dengan strategi yang sesuai. Akhirnya disepakati penerapan model kooperatif strategi konflik kognitif berbantuan KIT dan PhET. Kegiatan selanjutnya adalah penentuan skenario pembelajaran dan instrumen penilaian.

Tahapan-tahapan penting dalam pelaksanaan pembelajaran kooperatif strategi konflik kognitif berbantuan KIT dan PhET adalah sebagai berikut.

a. Siswa menyimak kompetensi dasar, petunjuk pembelajaran, dan mengecek perlengkapan pembelajaran, yaitu name tag yang dipasang di dadanya. Hal ini dimaksudkan untuk memudahkan observasi.

b. Siswa bergabung dalam kelompok, masing-masing kelompok terdiri dari 3 orang.

c. Siswa menyimak fenomena yang disajikan guru melalui PhET.

d. Guru menyajikan masalah berdasarkan fenomena tersebut dan meminta siswa mengajukan argumentasi hasil diskusi kelompoknya. Kemudian dikonfrontasi dengan argumentasi kelompok lain.

e. Guru mengkonfrontasi konsep melalui kegiatan eksperimen menggunakan KIT. Masalah yang disajikan sama dengan ketika siswa menganalisa fenomena melalui PhET. Siswa melakukan percobaan sederhana, menganalisis hasil, dan menjawab beberapa pertanyaan dalam Lembar Kerja Siswa (LKS).

f. Siswa diminta memberikan argumentasi kelompoknya terhadap kegiatan eksperimen dalam diskusi kelas. Argumentasi dikonfrontasi antar kelompok. Sambil mendengarkan argumentasi yang diutarakan, guru melakukan penilaian.

g. Guru memberikan ucapan selamat kepada kelompok yang memiliki argumentasi mendekati argumentasi ilmiah.

h. Guru menunjukkan argumentasi ilmiahnya sehingga siswa meninggalkan pelajaran dengan persepsi ilmiah yang sama.

i. Guru dan siswa melakukan refleksi tentang proses pembelajaran hari itu. Refleksi bertujuan memberikan penguatan kepada siswa tentang bagaimana menganalisa fenomena dan membuat argumentasi sebagai bekal untuk kegiatan 
berikutnya. Selain itu, siswa dan guru juga merefleksi proses pembelajaran untuk mengetahui kekurangan atau kelebihan tahapan-tahapan yang telah dilalui.

Pada pertemuan kedua, bahan diskusi tetap disajikan dalam bentuk PhET dan eksperimen. Pertemuan ketiga merupakan kelanjutan dari pertemuan kedua, langkah-langkahnya sama dengan pertemuan kedua.

Sebagai kegiatan penutup, guru dan siswa melakukan refleksi terhadap proses pembelajaran yang telah dilakukan selama tiga kali pertemuan. Siswa mengisi lembar angket yang disiapkan oleh guru.

Observasi/pengamatan dilakukan oleh peneliti dan observer. Peneliti mengamati aktivitas siswa yang berkaitan langsung dengan penilaian dalam proses belajar. Sedangkan, pengamatan observer difokuskan pada guru dan siswa yang melaksanakan pembelajaran. Dari hasil observasi diketahui bahwa keseluruhan aktivitas guru dalam pengelolaan pembelajaran sudah baik.

Hasil identifikasi CRI individu dan pengkodean argumentasi siklus I disajikan pada Gambar 5 dan Gambar 6.

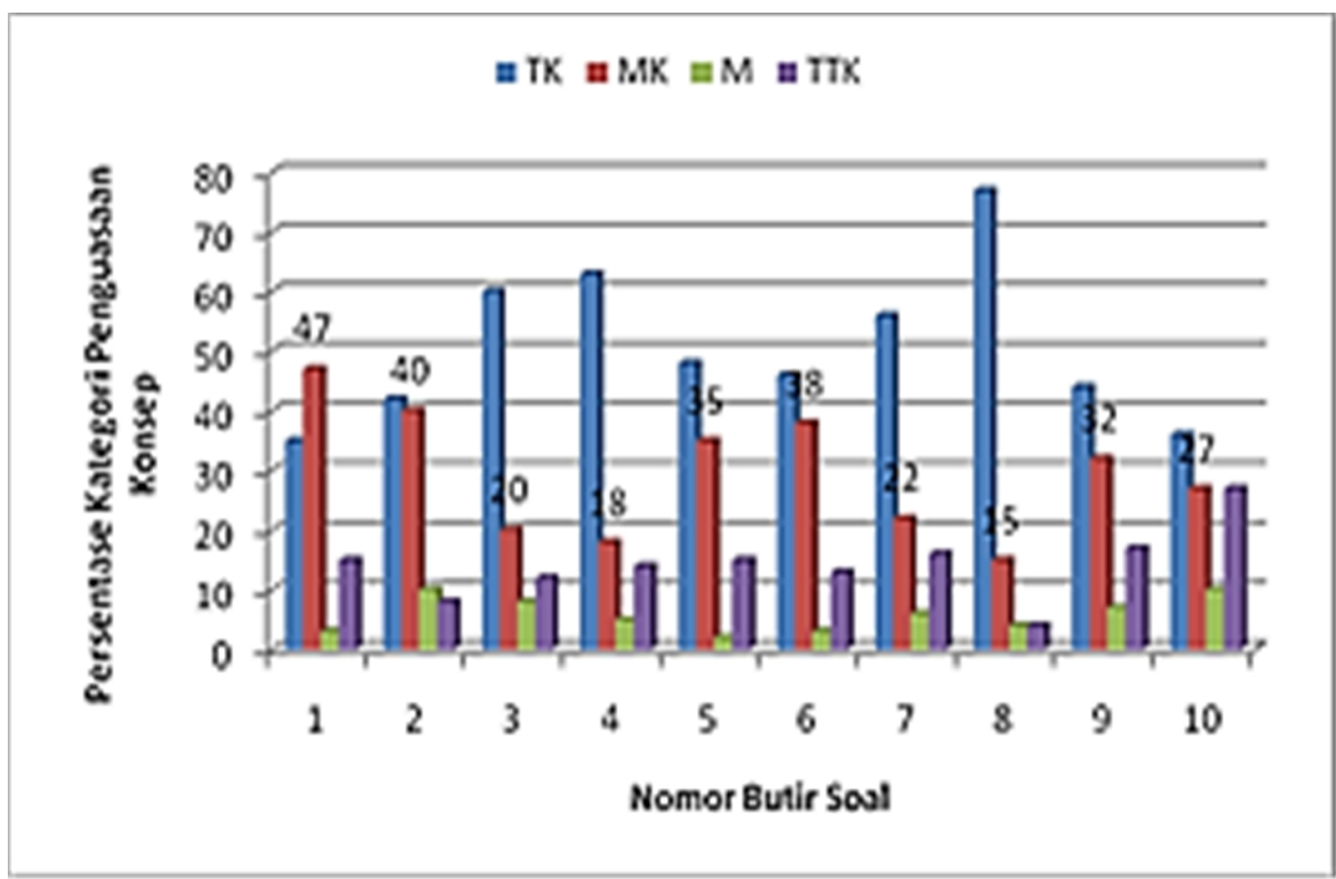

Gambar 5. Profil Tingkat Penguasaan Konsep Siswa

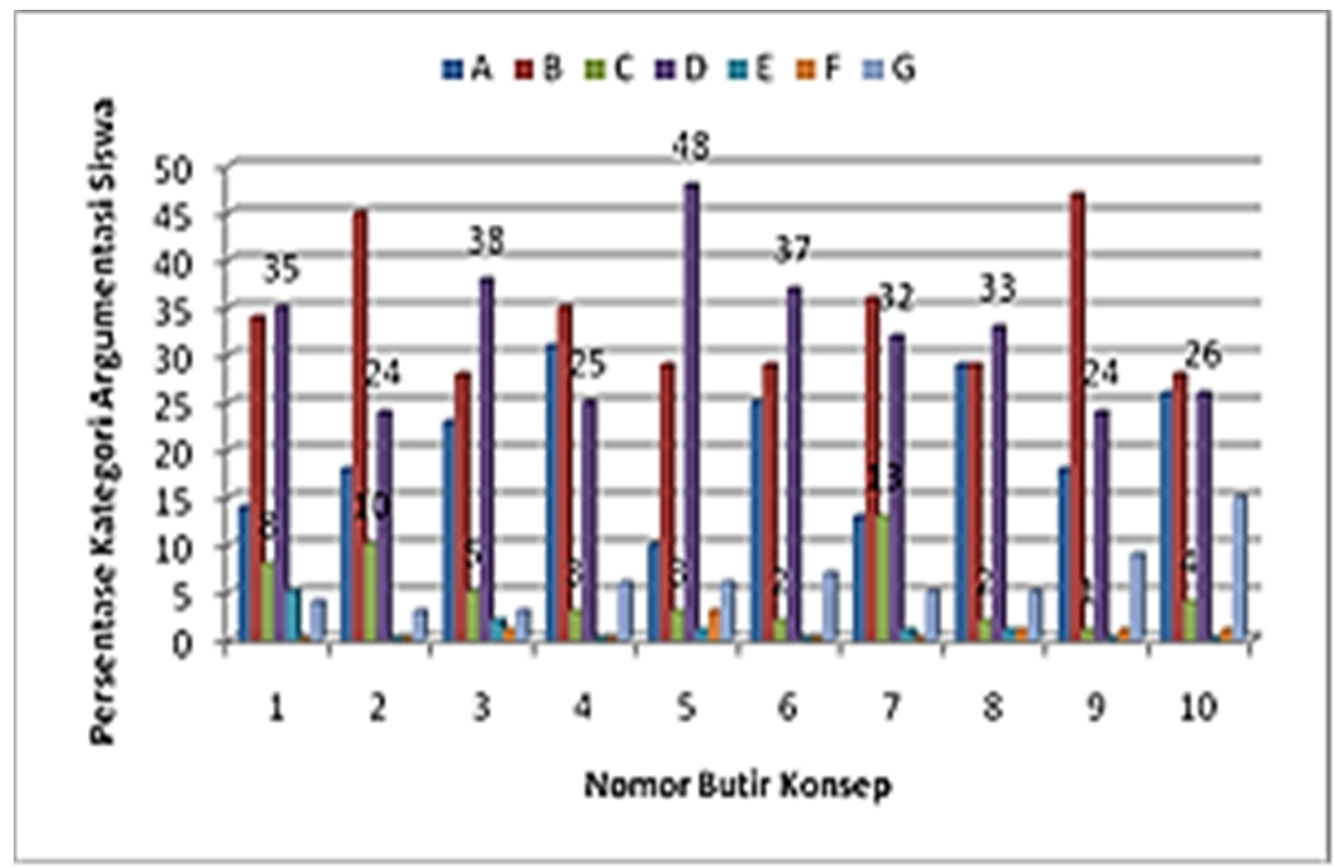

Gambar 6. Profil Miskonsepsi Argumentasi Siswa 
Berdasarkan hasil identifikasi profil miskonsepsi dengan menggunakan CRI secara individu pada Gambar 5 dan pengkodean argumentasi pada Gambar 6, terlihat bahwa siswa masih mengalami miskonsepsi terhadap delapan konsep yang diujikan, namun persentasenya telah mengalami reduksi.

Berdasarkan hasil identifikasi CRI pada Gambar 3 dan Gambar 5 dapat disimpulkan bahwa persentase jawaban siswa yang berada pada kategori miskonsepsi untuk tiap butir soal mengalami reduksi secara signifikan. Persentase reduksi miskonsepsi hasil analisis CRI untuk masing-masing butir soal disajikan pada Tabel 3 berikut.

Tabel 3. Daftar Persentase Reduksi Miskonsepsi

\begin{tabular}{|c|c|c|c|}
\hline \multirow{2}{*}{ No } & \multicolumn{2}{|c|}{ Persentase Miskonsepsi } & $\begin{array}{c}\text { Reduksi } \\
\text { Miskonsepsi }\end{array}$ \\
\cline { 2 - 4 } & Prapenelitian & Siklus I & 26 \\
\hline 1 & 73 & 47 & 15 \\
\hline 3 & 55 & 40 & 4 \\
\hline 4 & 24 & 20 & 12 \\
\hline 5 & 30 & 18 & 15 \\
\hline 6 & 62 & 35 & 24 \\
\hline 7 & 34 & 38 & 12 \\
\hline 8 & 30 & 15 & 15 \\
\hline 9 & 40 & 32 & 8 \\
\hline 10 & 31 & 27 & 4 \\
\hline
\end{tabular}

Sedangkan berdasarkan hasil identifikasi pengkodean argumentasi pada Gambar 4 dan Gambar 6 dapat disimpulkan bahwa persentase argumentasi siswa yang berada pada kategori miskonsepsi untuk tiap butir soal mengalami reduksi secara signifikan. Persentase reduksi miskonsepsi hasil analisis pengkodean argumentasi pada setiap butir soal disajikan pada Tabel 4.

Tabel 4. Reduksi Miskonsepsi Argumentasi

\begin{tabular}{|c|c|c|c|}
\hline \multirow{2}{*}{ No } & \multicolumn{2}{|c|}{ Persentase Miskonsepsi } & $\begin{array}{c}\text { Reduksi } \\
\text { Miskonsepsi }\end{array}$ \\
\cline { 2 - 4 } & Prapenelitian & Siklus I & Misk \\
\hline 2 & 67 & 43 & 13 \\
\hline 3 & 47 & 34 & 16 \\
\hline 4 & 59 & 43 & 22 \\
\hline 5 & 50 & 28 & 14 \\
\hline 6 & 65 & 51 & 31 \\
\hline 7 & 70 & 39 & 15 \\
\hline 8 & 46 & 45 & 11 \\
\hline 9 & 48 & 35 & 23 \\
\hline 10 & 54 & 25 & 24 \\
\hline
\end{tabular}

Identifikasi CRI secara kelompok pada siklus I disajikan pada Gambar 7.

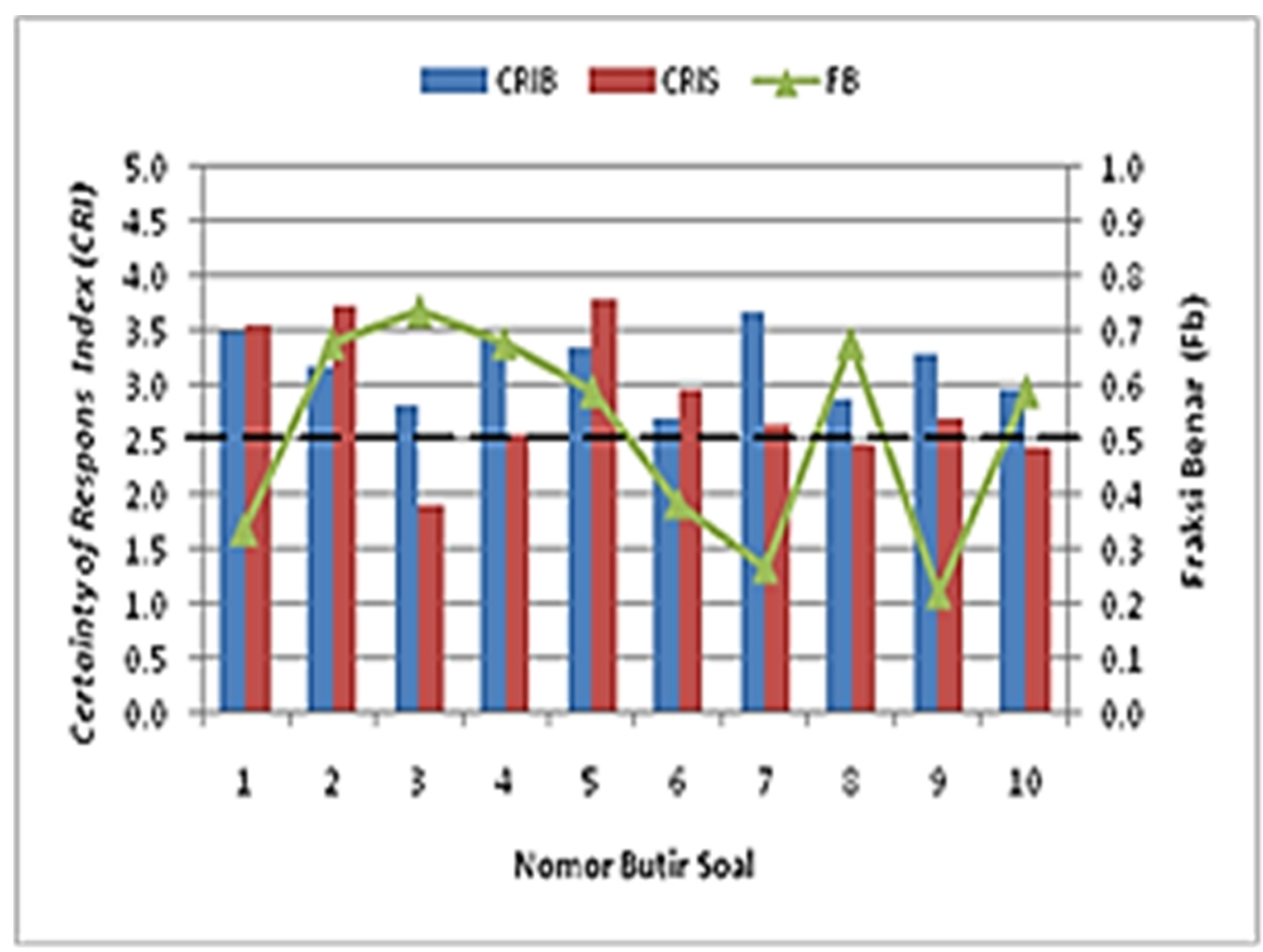

Gambar 7. Grafik Rerata CRIB, CRIS, dan Fb Siklus I 
Deskripsi Gambar 7 di atas dijabarkan sebagai berikut. Berdasarkan nilai CRIS, diketahui dari delapan konsep yang diujikan (10 butir soal), siswa mengalami miskonsepsi terhadap enam konsep, yaitu soal nomor 1 , $2,5,6,7$, dan 9. Soal nomor 2 dan 5 memiliki nilai CRIS $>2,5$ dengan $\mathrm{Fb}>0,5$. $\mathrm{Fb}>0,5$ menunjukkan bahwa persentase siswa yang menjawab benar untuk konsep tersebut adalah di atas 50\%. Hal ini mengindikasikan bahwa persentase siswa yang mengalami kesulitan dalam menjawab soal 2 dan 5 adalah rendah. Karena $\mathrm{Fb}>0,5$, berarti CRIS tergolong rendah, sehingga untuk konsep jarak dan perpindahan serta kelajuan dan kecepatan, siswa dianggap tidak tahu konsep. Soal nomor 9 atau konsep gerak lurus diperlambat memiliki nilai CRIS $>2,5$ dengan $\mathrm{Fb}=0,2$, dapat dikatakan sebagai konsep yang dampak miskonsepsinya sangat kuat, karena persentase siswa yang menjawab benar sama dengan $20 \%$.

Rerata penguasaan konsep siswa pada siklus I adalah 63,12 dengan ketuntasan 44,1\%. Hal ini menunjukkan bahwa rerata dan ketuntasan siswa masih berada di bawah KKM KD dan KKM klasikal, meskipun sudah mengalami kenaikan dibandingkan prapenelitian.

Berdasarkan hasil refleksi dari keseluruhan proses, baik data berasal dari peneliti, kolaborator, maupun balikan siswa, diperoleh kesimpulan sebagai berikut. Sesuai dengan data yang sudah disebutkan, model pembelajaran kooperatif strategi konflik kognitif berbantuan KIT dan PhET itu menyenangkan, memotivasi, dan mereduksi miskonsepsi siswa. Peneliti sudah mampu mengelola kelas dengan baik. Proses belajar siswa yang baik berkorelasi dengan peningkatan penguasaan konsep dan reduksi miskonsepsi pula. Model pembelajaran kooperatif strategi konflik kognitif berbantuan KIT dan PhET dinilai siswa dapat mereduksi miskonsepsi siswa. Pemilihan fenomena yang dapat memunculkan konflik kognitif memberikan semangat tersendiri bagi siswa, karena dekat dengan pengalaman sehari-hari.

Kelemahan pada siklus I ini masih belum tercapainya hasil yang maksimal karena miskonsepsi siswa bersifat resistan, sehingga mempengaruhi keoptimalan hasil belajar.

Berdasarkan hasil refleksi di atas, maka masih perlu tindakan berikutnya, yaitu siklus II. Pada siklus II, kelebihan-kelebihan harus ditingkatkan dan bentuk percobaan serta penyajian fenomena dalam bentuk eksperimen menggunakan KIT dan PhET harus dimodifikasi agar tidak membosankan. Sedangkan untuk mengatasi kelemahan, siswa harus lebih dimotivasi dan diberi materi berupa beberapa fenomena yang harus dianalisis agar dapat lebih terlatih berpikir kritis. Semua konsep yang diujikan masih perlu ditekankan kepada siswa melalui analisis fenomena dengan bantuan KIT dan PhET.

\section{Deskripsi Hasil Siklus Ii}

Tindakan pada siklus II tetap menggunakan model pembelajaran kooperatif strategi konflik kognitif berbantuan KIT dan PhET dengan sedikit modifikasi tanpa mengubah esensi dan akan menerapkan hasil refleksi siklus I.

Tahap perencanaan dilakukan setelah peneliti dengan dibantu observer berdiskusi tentang data yang telah dihasilkan dari kegiatan siklus I, baik catatan yang dibuat peneliti, observer, maupun balikan siswa.

Berdasarkan permasalahan yang ditentukan, peneliti menentukan alternatif pemecahan masalah dengan model yang sama karena terbukti model tersebut sesuai. Untuk penyempurnaan dan menghindari kejenuhan, model pembelajaran kooperatif strategi konflik kognitif berbantuan KIT dan PhET didesain ulang tanpa meninggalkan substansi aslinya. Kelebihan model ini dalam mereduksi miskonsepsi adalah: kooperatif berbasis tim, berpusat pada siswa, melibatkan siswa secara aktif, memanfaatkan multimedia, interaktif, dapat menstimulasi semua panca indera, dan menghadirkan fenomena dengan konteks dunia nyata harus ditingkatkan.

Kegiatan selanjutnya adalah penentuan skenario pembelajaran dan instrumen penilaian. Pembelajaran didesain tiga kali pertemuan, masing-masing pertemuan sebanyak dua jam pelajaran ( 2 x 45 menit).

Langkah-langkah yang dilakukan pada siklus II hampir sama dengan siklus I, yang berbeda hanya pada fenomena-fenomena untuk menciptakan konflik kognitif dalam bentuk eksperimen lanjutan menggunakan KIT dan PhET .

Pengamatan dilakukan oleh guru selaku peneliti dan guru sejawat selaku observer. Peneliti mengamati aktivitas siswa yang berkaitan langsung dengan penilaian dalam proses pembelajaran. Sedangkan, pengamatan observer difokuskan pada guru dan siswa yang melaksanakan pembelajaran.

Hasil pengamatan observer terhadap keterlaksanaan pembelajaran menunjukkan bahwa guru dan siswa dapat beradaptasi dengan baik terhadap perangkat pembelajaran kooperatif strategi konflik kognitif berbantuan KIT dan PhET.

Hasil identifikasi CRI individu dan pengkodean argumentasi siklus II disajikan pada Gambar 8 dan Gambar 9. 


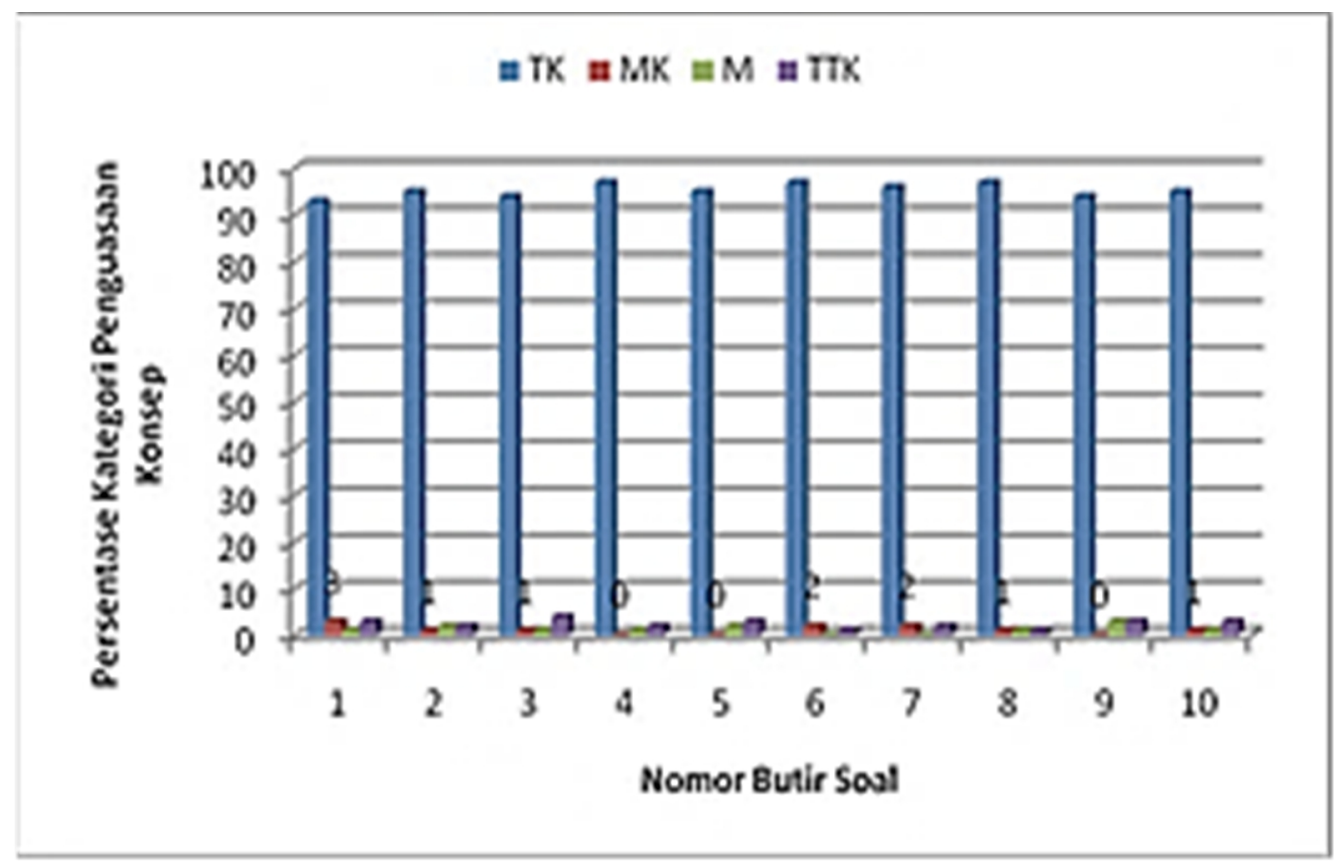

Gambar 8. Profil Tingkat Penguasaan Konsep Siswa

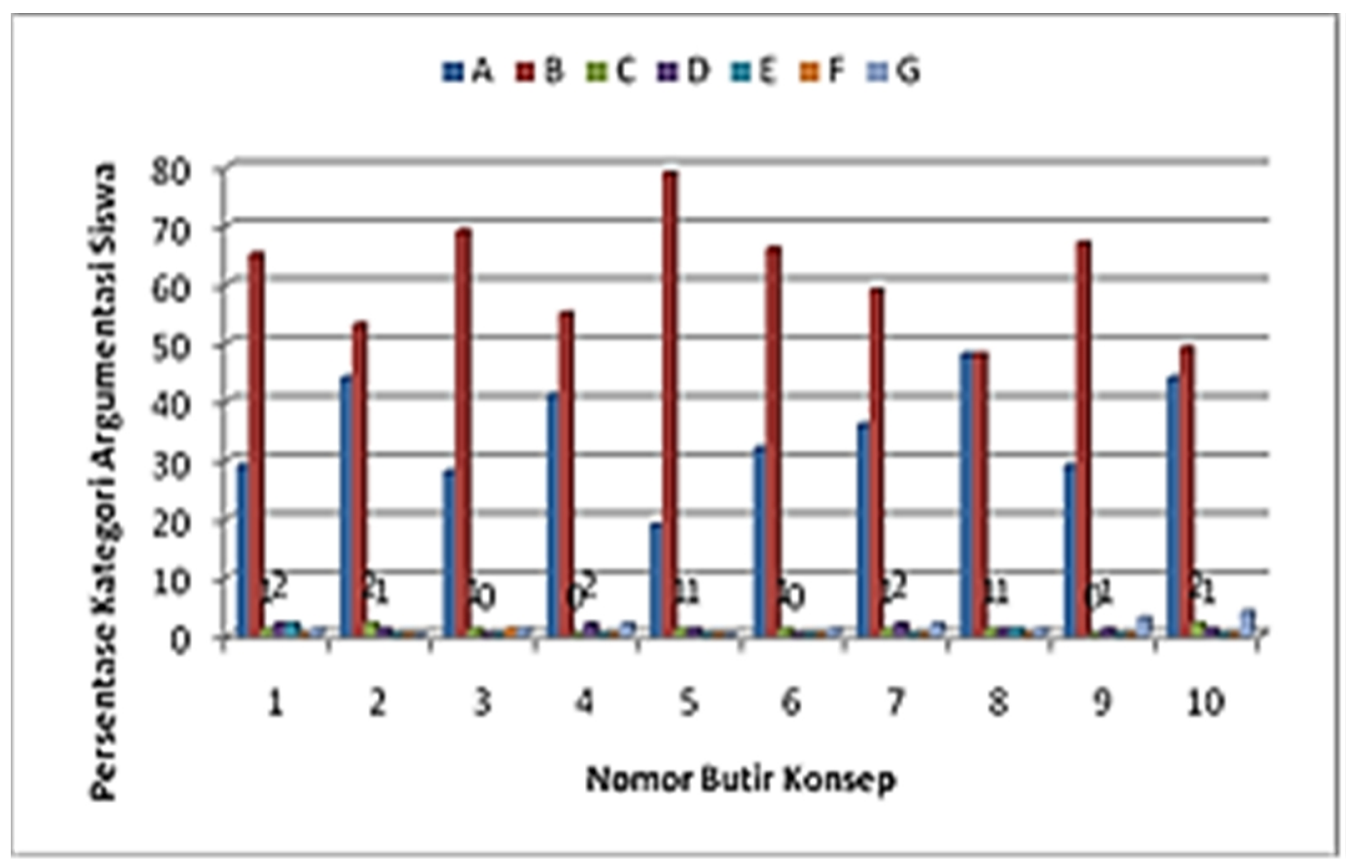

Gambar 9. Profil Miskonsepsi Argumentasi Siswa

Berdasarkan hasil identifikasi profil miskonsepsi dengan menggunakan CRI secara individu yang disajikan pada Gambar 8 dan pengkodean argumentasi pada Gambar 9, terlihat bahwa beberapa siswa masih mengalami miskonsepsi terhadap delapan konsep yang diujikan, namun persentasenya telah mengalami reduksi yang cukup besar dibandingkan siklus I.

Berdasarkan hasil identifikasi CRI secara individu yang disajikan pada Gambar 5 dan Gambar 8 dapat disimpulkan bahwa persentase jawaban siswa yang berada pada kategori miskonsepsi untuk tiap butir soal mengalami reduksi secara signifikan. Persentase reduksi miskonsepsi hasil analisis CRI untuk masing-masing butir soal disajikan pada Tabel 5 berikut.
Tabel 5. Persentase Reduksi Miskonsepsi

\begin{tabular}{|c|c|c|c|}
\hline \multirow{2}{*}{ No } & \multicolumn{2}{|c|}{ Persentase Miskonsepsi } & $\begin{array}{c}\text { Reduksi } \\
\text { Miskonsepsi }\end{array}$ \\
\cline { 2 - 3 } & Siklus I & Siklus II & 44 \\
\hline 1 & 47 & 3 & 39 \\
\hline 2 & 40 & 1 & 19 \\
\hline 3 & 20 & 1 & 18 \\
\hline 4 & 18 & 0 & 35 \\
\hline 5 & 35 & 0 & 36 \\
\hline 6 & 38 & 2 & 20 \\
\hline 7 & 22 & 2 & 14 \\
\hline 8 & 15 & 1 & 32 \\
\hline 9 & 32 & 0 & 26 \\
\hline 10 & 27 & 1 & \\
\hline
\end{tabular}

Reduksi Miskonsepsi kinematika Siswa Melalui Model Kooperatif ... 
Identifikasi miskonsepsi yang dialami siswa dapat ditelusuri dari argumentasi yang diberikan untuk memperkuat jawaban pada tiap butir soal. Hasil identifikasi miskonsepsi dengan menggunakan pengkodean argumentasi yang disajikan pada Gambar 6 dan Gambar 9 dapat disimpulkan bahwa persentase argumentasi siswa yang berada pada kategori miskonsepsi untuk tiap butir soal mengalami reduksi secara signifikan. Persentase reduksi miskonsepsi hasil analisis pengkodean argumentasi untuk masing-masing butir soal disajikan pada Tabel 6 berikut.

Tabel 6. Reduksi Miskonsepsi Argumentasi

\begin{tabular}{|c|c|c|c|}
\hline \multirow{2}{*}{ No } & \multicolumn{2}{|c|}{ Persentase Miskonsepsi } & $\begin{array}{c}\text { Reduksi } \\
\text { Miskonsepsi }\end{array}$ \\
\cline { 2 - 4 } & Siklus I & Siklus II & \\
\hline 1 & 43 & 3 & 40 \\
\hline 2 & 34 & 3 & 31 \\
\hline 3 & 43 & 1 & 42 \\
\hline 4 & 28 & 2 & 26 \\
\hline 5 & 51 & 2 & 49 \\
\hline 6 & 39 & 1 & 38 \\
\hline 7 & 45 & 3 & 42 \\
\hline 8 & 35 & 2 & 33 \\
\hline 9 & 25 & 1 & 24 \\
\hline 10 & 30 & 3 & 27 \\
\hline
\end{tabular}

Identifikasi CRI secara kelompok pada siklus II disajikan pada Gambar 10.

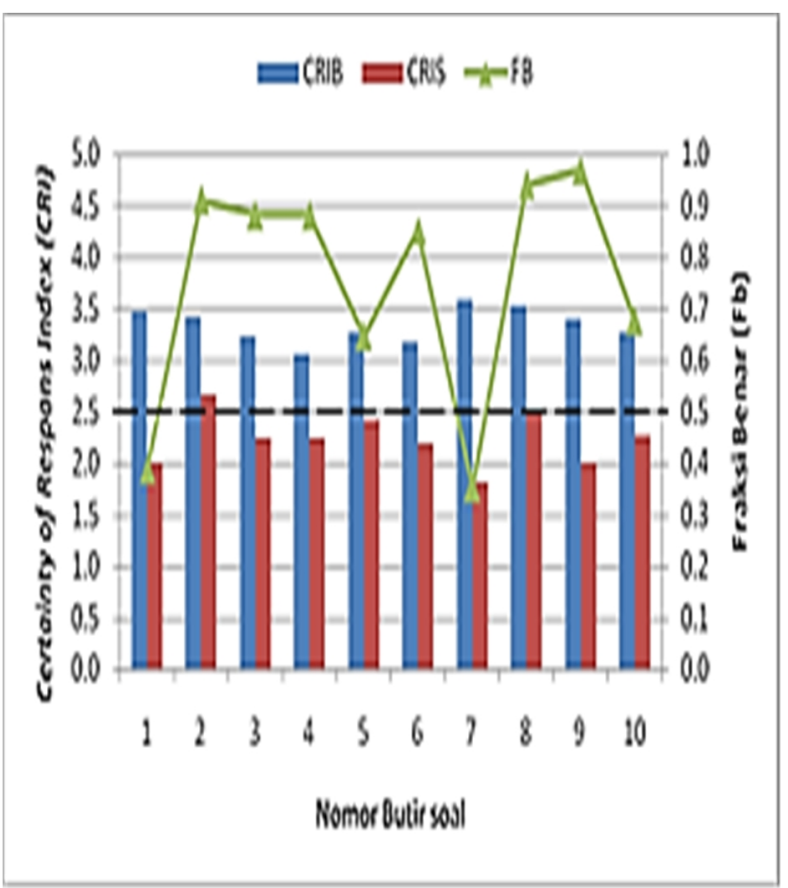

Gambar 10. Grafik Rerata CRIB, CRIS, dan Fb Siklus II

Deskripsi Gambar 10 di atas dijabarkan sebagai berikut. Berdasarkan nilai CRIS, diketahui dari delapan konsep yang diujikan (10 butir soal), terdapat siswa yang masih mengalami miskonsepsi terhadap satu konsep, yaitu jarak dan perpindahan atau soal nomor 2 . Soal nomor 2 memiliki nilai CRIS $>2,5$ dengan $\mathrm{Fb}>$ $0,5 . \mathrm{Fb}>0,5$ menunjukkan bahwa persentase siswa yang menjawab benar untuk konsep tersebut adalah di atas $50 \%$. Hal ini mengindikasikan bahwa persentase siswa yang mengalami kesulitan dalam menjawab soal nomor 2 adalah rendah. Karena $\mathrm{Fb}>0,5$, berarti CRIS tergolong rendah, sehingga untuk konsep jarak dan perpindahan, siswa dianggap tidak tahu konsep. Konsep-konsep gerak lurus dalam kehidupan seharihari (1) dan gerak lurus diperlambat (7) memiliki CRIS $<2,5$ dan $\mathrm{Fb}<0,5$. Siswa berada pada kategori tidak tahu konsep terhadap konsep-konsep tersebut.

Rerata penguasaan konsep siswa pada siklus II adalah 80,78 . Ketuntasan mencapai $91,2 \%$. Hal ini menunjukkan bahwa rerata dan ketuntasan siswa sudah di atas KKM KD dan KKM klasikal. Berdasarkan hasil refleksi dari keseluruhan proses, baik data berasal dari peneliti, kolaborator, maupun balikan siswa, diperoleh kesimpulan sebagai berikut. Model pembelajaran kooperatif strategi konflik kognitif berbantuan KIT dan PhET mampu mereduksi miskonsepsi siswa. Hal ini tidak terlepas karena desain pembelajaran dibuat menyenangkan, memotivasi, dan memberdayakan keterampilan berpikir kritis siswa. Baik Menurut observer dan siswa, guru (peneliti) sudah mampu mengelola kelas dengan baik.

Proses belajar siswa yang baik juga berkorelasi dengan pemerolehan nilai yang baik pula. Persentase ketuntasan yang tinggi mencerminkan peningkatan penguasaan konsep kinematika gerak lurus siswa. Kelemahan pada siklus II ini masih belum tercapai ketuntasan belajar $100 \%$, tetapi yang tidak tuntas relatif kecil, yaitu $3(8,8 \%)$ siswa.

Penggunaan model ini memerlukan kreativitas yang tinggi dalam menganalisis fenomena-fenomena yang disajikan. Oleh karena itu, peran guru sangat penting. Jika tidak, maka siswa yang tidak terpantau argumentasinya akan mengalami miskonsepsi.

Berdasarkan hasil refleksi di atas, maka peneliti memutuskan untuk menghentikan tindakan pada siklus II. Beberapa kekurangan masih bisa diperbaiki pada pembelajaran dengan kompetensi dasar yang lain.

\section{Deskripsi Antar Siklus}

Setelah dilakukan deskripsi tiap siklus, selanjutnya dilakukan deskripsi perkembangan antarsiklus untuk mendeskripsikan peningkatan yang dicapai dari satu siklus ke siklus berikutnya.

Hasil pelaksanaan tindakan pada siklus I dan II, termasuk peningkatan hasil prapenelitian direkapitulasi sebagai berikut. 
Tabel 7. Peningkatan Rerata Nilai antar Siklus

\begin{tabular}{|c|c|c|c|c|}
\hline \multirow{2}{*}{ Rerata } & \multicolumn{4}{|c|}{ Jumlah Siswa } \\
\cline { 2 - 5 } & Total & Tuntas & $\begin{array}{r}\text { Tidak } \\
\text { Tuntas }\end{array}$ & $\begin{array}{c}\text { Ketuntas } \\
\text { an }\end{array}$ \\
\hline 80,78 (S II) & & 31 & 3 & 91,2 \\
63,12 (S I) & 34 & 15 & 19 & 44,1 \\
41,39 (pra) & & 0 & 34 & 0,0 \\
\hline
\end{tabular}

Rerata penguasaan konsep siswa mengalami kenaikan yang signifikan dari prapenelitian yaitu 41,93 menjadi 63,12 pada siklus I, dan meningkat menjadi 80,78 pada siklus II. Sedangkan ketuntasan juga mengalami kenaikan signifikan yaitu dari $0 \%$ (prapenelitian) menjadi 44,1\% (siklus I), dan menjadi 91,2\% (siklus II).

Hasil refleksi siswa juga menunjukkan peningkatan kemampuan siswa dalam menganalisis fenomena setelah mengikuti pembelajaran kooperatif strategi konflik kognitis berbantuan KIT dan PhET. Siswa menilai model pembelajaran maupun kemampuan guru dalam mengelola pembelajaran cukup baik. Hasil refleksi siswa sangat berguna bagi guru dalam memperbaiki kelemahan-kelemahan pada saat tindakan.

Selanjutnya, untuk mengetahui apakah peningkatan penguasaan konsep yang terjadi pada siswa, diakibatkan oleh pembelajaran yang telah dilaksanakan, maka dilakukan analisis deskriptif n-gain (Hake, 1999). Hasil analisis n-gain disajikan pada Gambar 11.

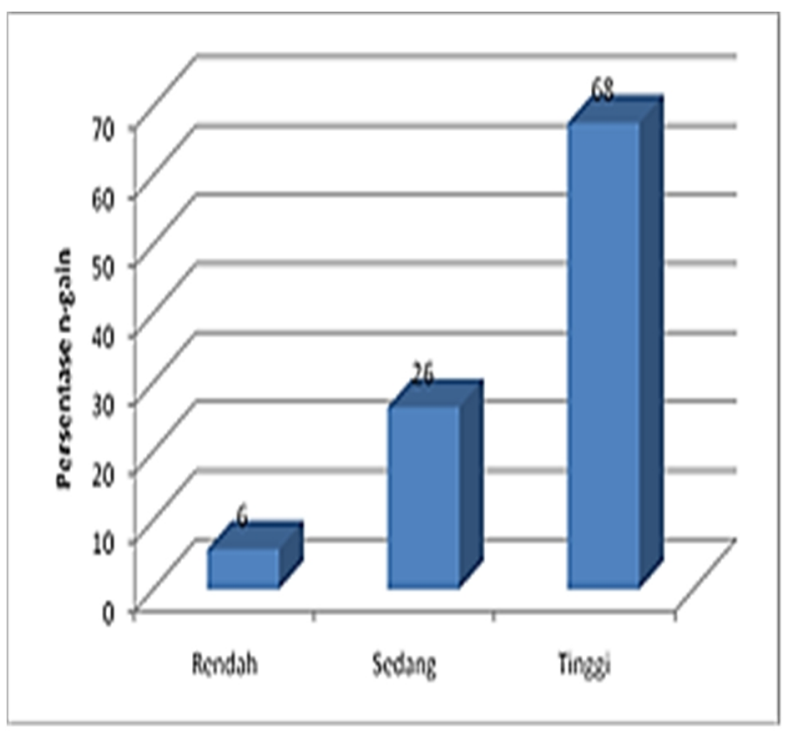

Gambar 11. Ringkasan Hasil Analisis n-gain

Berdasarkan hasil analisis tersebut dapat dilihat bahwa persentase n-gain terbesar berada pada kategori tinggi, sedangkan terkecil pada kategori rendah, sehingga dapat disimpulkan bahwa pembelajaran kooperatif dengan strategi konflik kognitif berbantuan KIT dan PhET efektif dalam meningkatkan penguasaan konsep siswa. Dengan meningkatnya penguasaan konsep, maka miskonsepsi siswa akan tereduksi.

Melihat pencapaian indikator-indikator penelitian antar siklus dapat dinyatakan bahwa penerapan model kooperatif strategi konflik kognitif berbantuan KIT dan PhET dapat meningkatkan penguasaan konsep dan mereduksi miskonsepsi siswa kelas X IPA 2 SMAN 2 Bontang.

Keberhasilan tersebut tampak pada keseluruhan elemen yang menjadi fokus penelitian dari tahapan demi tahapan, mulai dari peningkatan nilai rata-rata tiap konsep, nilai rata-rata siswa, dan reduksi miskonsepsi siswa, sampai dengan peningkatan ketuntasan kelas. Peningkatan juga tampak pada proses pembelajaran. Hasil refleksi siswa pun mengindikasikan adanya peningkatan yang signifikan, terutama pada rasa percaya diri untuk dapat berargumentasi atau mengkritisi fenomena dengan baik sesuai konsepsi ilmiah.

Desain pembelajaran yang kooperatif berbasis tim yang berpusat pada siswa dengan memanfaatkan multimedia interaktif yang dapat menghadirkan fenomena dengan konteks dunia nyata, yang dapat menstimulasi semua panca indera sehingga siswa menjadi aktif, ternyata mampu meningkatkan keberanian dan rasa percaya diri dalam mengkritisi fenomena dan menyampaikan hasilnya baik dalam diskusi kelompok maupun dalam diskusi kelas.

Dengan memberikan materi (fenomena) dalam bentuk gambar dan video, yang diramu dari berbagai sumber, pemberian motivasi, percobaan sederhana, desain pembelajaran kooperatif strategi konflik kognitif berbantuan KIT dan PhET memberikan kemudahan dan mengurangi rasa malu atau tidak percaya diri, serta memberikan pengalaman langsung kepada siswa untuk bertindak dan menemukan konsep yang sesuai dengan konsepsi ilmiah.

\section{KESIMPULAN}

Berdasarkan hasil refleksi dari keseluruhan proses, baik data berasal dari peneliti, kolaborator, maupun balikan siswa, diperoleh kesimpulan sebagai berikut. Model pembelajaran kooperatif strategi konflik kognitif berbantuan KIT dan PhET itu menyenangkan, memotivasi, dan mereduksi miskonsepsi siswa. Peneliti sudah mampu mengelola kelas dengan baik. Proses belajar siswa yang baik berkorelasi dengan peningkatan penguasaan konsep dan reduksi miskonsepsi pula. Hasil penelitian menunjukkan bahwa rata-rata penguasaan konsep siswa dan ketuntasan meningkat dari 41,93 dan 0\% (prapenelitian) menjadi 63,12 dan 44,1\% (siklus I) kemudian menjadi 80,78 dan 91,2\% (siklus II). 
Hasil analisis CRI dan pengkodean argumentasi menunjukkan bahwa miskonsepsi yang dialami siswa mengalami reduksi dengan persentase sebagai berikut: konsep gerak lurus dalam kehidupan sehari-hari tereduksi $70 \%$ dan 64\%, konsep jarak dan perpindahan tereduksi $39 \%$ dan $51 \%$, konsep kelajuan dan kecepatan tereduksi $40 \%$ dan 56\%, konsep percepatan tereduksi $60 \%$ dan $69 \%$, konsep gerak lurus beraturan tereduksi $32 \%$ dan $37 \%$, konsep gerak lurus berubah beraturan tereduksi $29 \%$ dan $44 \%$, konsep gerak lurus diperlambat tereduksi $40 \%$ dan $47 \%$, serta konsep gerak jatuh bebas tereduksi $30 \%$ dan $51 \%$.

Berdasarkan hasil temuan penelitian yang dilakukan, peneliti memberikan saran bahwa perlu diterapkan model pembelajaran kooperatif dengan strategi konflik kognitif berbantuan KIT dan PhET untuk mereduksi miskonsepsi siswa pada materi lain.

\section{REFERENSI}

Baser, M. (2006). Forstering Conceptual Change By Cognitive Conflict Based Instruction on Students' Understanding of Head and Temperature Concepts. Eurasia Journal of Mathematics, Science and Technology Education. 2(2).

Dilber, R. \& Duzgun, B. (2007). An Investigation of Effectiveness of Conceptual Change TextOriented Instruction on Students' Understanding of Brigthness Concepts. Journal of Science Education-ProQuest Education Journals. 8(1), 46-52.

Dilber, R. \& Duzgun, B. (2008). Effectiveness of Analogy on Student's Success and Elimination of Misconcepcions. Journal of Science Education. 2(3), 174-183.

Faizin, M. N. (2009). Interactive Flash Modelliling (IMF) Usage to Reduce Mosconception in Dynamic Electrical and ti Improve The Students's Learning Attitude. Proceeding of The Third Internasional Seminar on Science Education. 516-525.

Hasan, S, Bagayoko, D, \& Kelly, E. L. (1999). Misconception and The Certainty of Response Index. Journal of Physics Education. 34(5).

Hake, R. R. (1999). Interactive-engagement Methods in Introductory Mechanics Courses. Journal of Physics Education Research.

Ibrahim, M. (2012). Seri Pembelajaran Inovatif Konsep, Miskonsepsi, dan Cara Pembelajarannya. Surabaya: Unesa University Press.

Indrawati. (2009). The Misconception of Physics Teacher Prospective Students about Law of Reflection. Proceeding of The Third
Internasional Seminar on Science Education. 244-250.

Kucukozer, H. \& Kocakulah, S. (2007). Secondary School Students' Misconception about Simple Electric Circuits. Jurnal of Turkish Science Education. 4(1), 101-116.

Mardana, I. (2004). Pengembangan Model Simulasi Komputer Berorientasi Konstruktivisme Sebagai Inovasi Teknologi Pembelajaran Pengubah Miskonsepsi untuk Meningkatkan Hasil Belajar Fisika Siswa SMU. Jurnal Pendidikan dan Pengajaran IKIP Negeri Singaraja. (4), 57-71.

Mosik, M. P. (2010). Usaha Mengurangi Terjadinya Miskonsepsi Fisika Melalui Permbelajaran dengan Pendekatan Konflik Kognitif. Jurnal Pendidikan Fisika Indonesia. 98-103.

Mukti, A.D.Y., Raharjo, T., \& Wiyono, E., (2010). Identifikasi Miskonsepsi dalam Buku Ajar fisika SMA Kelas X Semester Gasal. Jurnal Materi dan Pembelajaran Fisika (JMPF). 1(1), 39-41.

Mudjiarto, R., (2005). Peningkatan Pemahaman Konsep Dasar Fisika Melalui Pendekatan pembelajaran Konseptual Secara Interaktif. Mimbar Pendidikan. (2), 17-24.

Pujianto, A., Nurjannah., \& Darmadi, I.W., (2013). Analisis Konsepsi Siswa pada Konsep Kinematika Gerak Lurus. Jurnal Pendidikan Fisika Tadulako (JPFT). 1(1), 16-21.

Raduta, C. (2005). General Students' Misconception Related to Electricity and Magnetism. The Ohio State University: Physics Departement.

Sadia, I W. (2004). Efektivitas model Konflik Kognitif dan Model Siklus Belajar untuk Memperbaiki Miskonsepsi Siswa dalam Pembelajaran Fisika. Jurnal Pendidikan dan Pengajaran IKIP Negeri Singaraja. (3), 40-58.

Saehana, S. \& Haeruddin. (2009). Development of Computer Simulation in Cooperative Learning Model to Minimize The Misconception Physics in High School Students in Palu. Tadulako University. Proceeding of The Third Internasional Seminar on Science Education. Science Education Program, Graduate School. Indonesia University of Education (IUE). 516525.

Said, M. U. (2012). Pengembangan Perangkat Pembelajaran Berbasis Lab Mini untuk Meremidiasi Miskonsepsi Siswa SMA. Tesis: PPs. Unesa.

Samsuri. (2010). Pengembangan Perangkat Pembelajaran Berbasis Media Simulasi PhET dan KIT Sederhana Pada Pembelajaran Fisika 
SMA Pokok Bahasan Listrik Sederhana. Tesis: PPs. Unesa.

Simarmata, U. (2008). Penerapan Model Konstruktivis dalam Pembelajaran Fisika di SMU dalam Upaya Menanggulangi Miskonsepsi Siswa. Jurnal Pendidikan Matematika dan Sains. ISSN: 1907-7157. 2(3), 77-82.

Sirait, J. (2009). Cognitive Conflict Approach to Increase Critical Thinking of The Students in Physics. Proceeding of The Third Internasional Seminar on Science Education. 429-438.

Smith, D. P. \& Kampen, P. V. (2011). Teaching Electric Circuits with Multiple Batteries: A qualitative Approach. Journal of American Physical Society.

Triyanta. (2009). Medan Magnetik sebagai Efek Relativistik dari Gaya Coulomb dan Miskonsepsi yang Terkait dalam Pembelajaran
Kemagnetan. Jurnal Pengajaran Fisika Sekolah Menengah. 1(2), 40-47.

Trumper, R. (1990). Being Conctructive: An Alternatif Approach to The Teaching of Energy Concept. International Journal of Science Education. 12(4), 343-354.

Tsai, C.-H. Chen, H-Y., Chou, C-Y., \& Lain, K-D. (2007). Current as the Key Concept of Taiwanese Students' Understanding of Electric Circuits. International Journal of Science Education. 29(4), 483-496.

Trumper, R. (1990). Being Conctructive: An Alternatif Approach to The Teaching of Energy Concept. International Journal of Science Education. 12(4), 343-354.

Tsai, C.-H. Chen, H-Y., Chou, C-Y., \& Lain, K-D.

(2007). Current as the Key Concept of Taiwanese

Students' Understanding of Electric Circuits.

International Journal of Science Education. 29(4), 483496. 